\title{
Medium-run projections for greenhouse gas emissions arising from agriculture: the case of milk production in Estonia
}

\author{
Jelena Ariva, Ants-Hannes Viira, Reet Põldaru, Jüri Roots \\ Institute of Economics and Social Sciences \\ Estonian University of Life Sciences \\ Kreutzwaldi 1, 51014 Tartu \\ Estonia \\ e-mail: ants.viira@emu.ee
}

\begin{abstract}
In order to respond to increasing global food demand and provide for national economic growth, the Estonian Dairy Strategy for 2012-2020 aims to achieve a 30\% growth in milk production. At the same time, there is a global attempt to reduce greenhouse gas (GHG) emissions. This paper analyses the medium-term (2015-2020) projections for milk production and associated GHG emissions from dairy cows in Estonia. The FAPRI-GOLD type market model of Estonian agriculture, which is used for projections of agricultural production, was supplemented with a module that helps project GHG emissions. The paper demonstrates the endogenisation of GHG emission factors in a relatively general agricultural market model context. The results imply that increasing milk production by $30 \%$ by 2020 would jeopardise Estonia's commitments with regard to agricultural GHG emissions. However, the average GHG emission per tonne of produced milk will decline, thus reducing the "carbon footprint" of milk production.
\end{abstract}

Key words: partial equilibrium modelling, carbon footprint, sustainable intensification, Estonian agriculture, greenhouse gas emissions

\section{Introduction}

In the coming decades, humanity faces a common challenge: how to increase food production to sustain global food security, while maintaining negative externalities at the lowest possible level, and potentially eliminating these with the help of advanced technologies (Ingram et al. 2010, OECD 2012a, OECD 2012b, Gerber et al. 2013). Climate change is one of the environmental problems related to the broader concept of sustainable agriculture that encompasses economic, social and environmental pillars (Von Keyserlingk et al. 2013).

Several international agreements (United Nations Framework Convention on Climate Change [UNFCCC 2014a], Kyoto Protocol, EU Climate and Energy package) aim to reduce GHG emissions in the long term (EC 2014, EC 2015, UNFCCC 2014b, UNFCCC 2014c). From 1990-2012, in the EU the GHG emissions have declined by 19.2\%, and in Estonia by $52.8 \%$. In the agricultural sector, the respective cutbacks in emissions were $24.0 \%$ and $58.3 \%$ (Estonian CRF 2014, EU CRF 2014). One of the reasons behind the extensive decline of agricultural GHG emissions in Estonia is significant decline in agricultural output during the post-communist transition (Viira et al. 2009).

However, the decrease of milk production and associated GHG emissions is not one-way trend throughout the period from 1990-2014. While from 1990-2003 milk production in Estonia decreased by $49.4 \%$ to 611.5 thousand tonnes, after the EU accession in 2004 , by 2014 , it has increased by $30.7 \%$ to 799.3 thousand tonnes. As a response to elimination of the milk quotas in the EU, and expected increase in global demand for dairy products, the Estonian dairy strategy aims to increase annual milk production by further $1 / 3$ to approximately one million tons by 2020 compared to 2012, foreseeing growth in average milk yields and the number of dairy cows (MoA 2012).

Milk and meat production emit the largest share of GHG (primarily $\mathrm{CH}_{4}$ ) in animal production (Casey and Holden 2005, Bannink et al. 2011, O'Mara 2011, Gerber et al. 2013, Van Doorslaer et al. 2015). Estonia is required to ensure that GHG emissions in agriculture in 2020 do not exceed $111 \%$ of the 2005 levels (MoA 2013). Considering the $30.7 \%$ growth in milk production from 2003-2014, the aim to increase production by further $1 / 3$ suggests that while Estonian agricultural sector probably has no problems with fulfilling the long-term target of $20 \%$ reduction of GHG emissions from 1990-2020, the dairy sector might exceed the allowed $11 \%$ growth of GHG emissions in the medium-term (2005-2020). While realising the ambitious growth targets would contribute to economic welfare in Estonian rural communities, and global food security, the dairy strategy pays less attention on environmental aspects of sustainability. 
Thus, the paper aims to study the effects of increasing Estonian milk production by $1 / 3$ on associated GHG emissions. Rather than combining the production growth estimates with the static GHG emission factors, the GHG emissions are endogenised. The projections consider the effects of milk yield, milk fat and protein content, and changes in manure management systems on the GHG emission factors. For that purpose FAPRI-GOLD type partial equilibrium model (Hanrahan 2001, Meyers et al. 2010) of Estonian agriculture is complemented with a module for projections of GHG emissions from animal production based on IPCC (Intergovernmental Panel on Climate Change) Tier 2 methodology. Baseline projections are compared with the results of the particular scenario, which assumes accelerated growth in average yield and an increase in the number of dairy cows in order to achieve the production growth target set in the Estonian Dairy Strategy 2012-2020.

The next section of the paper provides more details related to the problem and its background. Then, the overview is given about materials and methods used for complementing the Estonian agricultural model with a module for projections of GHG emissions. After that, the results are presented and discussed, and the main conclusions are drawn.

\section{Background of the problem}

Nowadays, climate change, and global warming in particular, is primarily associated with increasing anthropogenic GHG (carbon dioxide $\left[\mathrm{CO}_{2}\right]$ and non- $\mathrm{CO}_{2}$ gases: methane $\left[\mathrm{CH}_{4}\right]$, nitrous oxide $\left[\mathrm{N}_{2} \mathrm{O}\right]$, fluorinated greenhouse gases [F-GHG]) emissions, which, in the long-term, cause changes in all components of the Earth's climate system (USEPA 2012, IPCC 2015).

While the energy sector is the main source of the $\mathrm{CO}_{2}$ emissions, agriculture is the biggest emitter of non- $\mathrm{CO}_{2}$ gases (USEPA 2012, IPCC 2015). The main GHGs that originate from agriculture are $\mathrm{CO}_{2}, \mathrm{CH}_{4}$ and $\mathrm{N}_{2} \mathrm{O}$. While agricultural animals are the main source of $\mathrm{CH}_{4}$ and $\mathrm{N}_{2} \mathrm{O}$ emissions, $\mathrm{CO}_{2}$ emissions are associated with soils and agricultural operations (e.g. fossil fuel use for field operations, manufacturing of fertilisers and animal feed) (Crosson et al. 2011, O’Mara 2011, Hristov et al. 2013, Van Doorslaer et al. 2015).

Due to the significant decline in agricultural GHG emissions, and agriculture's relatively low (6.9\%) contribution to total GHG emissions in Estonia (Estonian CRF 2014), the EU target to curb GHG emissions by $20 \%$ by 2020 , compared to 1990, are perceived as attainable. Furthermore, the low-income countries in the EU are allowed to increase GHG emissions within certain limits.

In addition to projection of total GHG emissions and respective changes, studies of effects on climate often analyse the GHG emissions per unit of produce. Several studies have shown that increase in average milk yields decreases GHG emissions per kg of milk, thereby reducing the carbon footprint of food production (MoE 2001, Casey and Holden 2005, Rotz et al. 2010, von Keyserlingk et al. 2013, AHDB 2014). Von Keyserlingk et al. (2013) outline feeding system, animal housing, manure collection, treatment and storage, and land application as the main factors that affect GHG emissions in dairy farms. Thus, the main alternatives for reducing GHG emissions in dairy farms in environmentally and economically sustainable way are: increase milk yields in order to produce the same quantity of milk with fewer cows, which assumes optimisation of feeding ratios, genetic selection, animal health and welfare attributes as well as reproduction strategies (Casey and Holden 2005, Gerber et al. 2013, Opio et al. 2013, Frelih-Larsen et al. 2014, Van Doorslaer et al. 2015); introduce improved feeding technologies that affect enteric fermentation in an environmentally friendly way and will not reduce milk yields (Grainger and Beauchemin 2011, Gerber et al. 2013, Opio et al. 2013); introduce manure management technologies that reduce GHG emissions and/or leakages and use manure for biogas production (Gerber et al. 2013).

For decades, milk production has been one of the most important agricultural sectors in Estonia. In 2014, milk comprised $27.8 \%$ of the value of Estonian agricultural output. While the number of dairy cows decreased by $66.1 \%$ from 280.7 to 95.1 thousand from $1990-2014$, milk production decreased by $33.8 \%$ from $1,208.0$ to 799.3 thousand tonnes due to the $97.1 \%$ growth in average yield (from 4,164 to 8,206 kg cow ${ }^{-1}$ ) (SE 2015). After the EU accession in 2004, the availability of subsidies for investments improved significantly, therefore Estonian dairy farmers have made substantial investments into new technologies, including housing, feeding, milking and manure management systems (MoA 2012). Therefore, the medium-term projections of GHG emissions in Estonian dairy sector should be conducted in a dynamic setting and account for the factors that affect GHG emissions, and changes in those factors. 


\section{Material and methods Approaches for estimating GHG emissions}

Two prevailing approaches for estimating GHG emissions are the IPCC methodology and life cycle assessment (LCA). The LCA approach facilitates estimating GHG emissions and the environmental effects of the whole (production) system, i.e. the effects arising from primary and secondary sources. It is based on a cyclical system of production and/or services and encompasses a range of activities from the production and logistics of inputs required for primary production to the utilisation of residues related to the use of the final products ("cradle-to-grave" approach). This approach requires determining bounds: the start and end points of the system. In animal production, the LCA approach often considers the GHGs emitted by animals (including manure management) as well as emissions related to feed production and land use (Casey and Holden 2005, SAIC 2006, Rotz et al. 2010, Crosson et al. 2011, Weiss and Leip 2012, Gerber et al. 2013). Several studies that have used the LCA approach have used GHG emission factors provided by the IPCC methodology or adjusted emission factors from previous research (Crosson et al. 2011, Weiss and Leip 2012, Lengers et al. 2013, Opio et al. 2013).

The IPCC guidelines provide a consistent, standard framework for estimating national GHG emissions. For this, national statistical data regarding energy and fossil fuel consumption, fertiliser sales, animal stock, land use and GHG emission factors for each activity are used. The source and precision of the emission factors (EF) play a crucial role in the estimations of GHG emissions. The IPCC methodology allows for estimating non- $\mathrm{CO}_{2} \mathrm{GHG}$ emissions that originate from animal production according to the main sources: enteric fermentation $\left(\mathrm{CH}_{4}\right)$ and manure management $\left(\mathrm{CH}_{4}\right.$ and $\left.\mathrm{N}_{2} \mathrm{O}\right)$. In this approach, the $\mathrm{GHG}$ emitted by dairy cows depends on the stock of animals and respective EF, which in turn depend on feeding ratios, feeding conditions, body weight and productivity of dairy cows as well as on manure management systems. The IPCC guidelines provide three levels of EFs for estimating GHG emissions. Tier 1 is a simplified approach that uses implicit EFs as provided in studies. It is used if the information necessary for applying Tier 2 is unavailable, or if the source categories of the GHG emissions are not the primary concern. The Tier 2 approach requires detailed information on livestock subcategories, their diets and management circumstances. Tier 3 requires detailed information about animal production (e.g. composition and quality of animal feeds) that could be retrieved from experimental measurements and studies (Bannik et al. 2011, Crosson et al. 2011, IPCC 2014).

Various approaches have been used for projecting GHG emissions in animal production: the projection of animals stock combined with static EFs; the projection of EFs combined with fixed animal stock; and the combination of both projected EFs and number of animals. In 'The possibilities for Estonia to reach a competitive low carbon economy by 2050' report, the projections for GHG emissions are based on EFs as presented in Estonian NIR and three projections of animal stock, each using fixed annual growth rates until 2050 (Espenberg et al. 2013). Donnellan et al. (2013) used the FAPRI-Ireland partial equilibrium model to project GHG emissions. The projected emissions were a result of the projected number of bovine animals and EFs adjusted to Irish conditions. In the EcAMPA project report (Van Doorslaer et al. 2015), an upgraded CAPRI model was used, which helped endogenously project animal stocks and EFs according to IPCC Tier 2 guidelines, by considering feed intake in gross energy, which can be estimated, if necessary, from parameters that characterise animal needs, such as weight and milk yield. Several studies have analysed how to reduce GHG emissions from enteric fermentation by changing feeding (feed attributes, components, additives, quantities, etc.) (Bannik et al. 2011, Grainger and Beauchemin 2011, Hristov et al. 2013).

\section{Estonian agricultural model}

The Estonian agricultural model allows one to project medium-term developments in the production of agricultural commodities, underlying animal stock, agricultural area and yields. An approach based on FAPRI-Missouri's EU GOLD model (Hanrahan 2001, Meyers et al. 2010) is used to create the overall agricultural model, which includes several sub-models. The model consists of a system of equations that cover the dairy, beef, sheep, pigs, poultry, and grain and rapeseed sectors. There is also a block for welfare estimations (Põldaru et al. 2015). In the model, the prices of the main agricultural commodities depend on the world market prices. The model uses world market prices of dairy products that are projected by global macroeconomic model of dairy production. That model considers five main regions of dairy production and consumption: EU, USA, China, Oceania and Russia. The prices are determined by following factors: lagged (previous year) price, per capita consumption of dairy products, stocks, Euro/USD exchange rate, and oil price in world market (Põldaru et al., 2013). 
The model includes a GHG sub-model to project the $\mathrm{CH}_{4}$ and $\mathrm{N}_{2} \mathrm{O}$ emissions and their effect on the climate $\left(\mathrm{CO}_{2}-\right.$ eq) from animal production (Fig. 1). As the model projects the number of dairy cows and milk yield, the study focuses on projections of $\mathrm{CH}_{4}, \mathrm{~N}_{2} \mathrm{O}$ and $\mathrm{CO}_{2}$-eq that are based on the respective projections. $\mathrm{CO}_{2}$ emissions from livestock are not estimated because annual net $\mathrm{CO}_{2}$ emissions are assumed to be zero - the $\mathrm{CO}_{2}$ photosynthesised by plants is returned to the atmosphere as respired $\mathrm{CO}_{2}$ (IPCC 2014).

Although the $\mathrm{N}_{2} \mathrm{O}$ arising from manure left on grasslands during grazing (i.e. pasture, range and paddock) is usually accounted as an indirect $\mathrm{N}_{2} \mathrm{O}$ emission from soils (Crosson et al. 2011, IPCC 2014), this study includes it as a portion of GHG emissions from milk production. Therefore, the grazing of dairy cows is deemed a manure management system. The GHG EFs from enteric fermentation and manure management are in accordance with the Tier 2 methodology. Emission factors per cow are endogenous, depending on average yield, milk fat and protein composition as well as manure management systems.

The study and the results are subject to several limitations. Figure 1 depicts that the study considers only $\mathrm{CH}_{4}$ emissions arising from enteric fermentation of dairy cows, and $\mathrm{CH}_{4}$ and $\mathrm{N}_{2} \mathrm{O}$ emissions from manure management (IPCC approach). Therefore, the results of this study cannot be compared to the results of studies that have used LCA approach (e.g. Rotz et al. 2010, Crosson et al. 2011, Weiss and Leip 2012). Due to the lack of respective timeseries data, this study does not consider the effects of characteristics of feed, feeding situation and diet, average gross energy intake and average annual body weight of dairy cows, fraction of females that give birth in a year, which all would improve the precision of projections of EFs and GHG emissions. If one considers that in addition to milk, dairy cows produce also meat (culled cows), the arising GHG emissions could be divided between milk and meat production, which is not done in this paper.

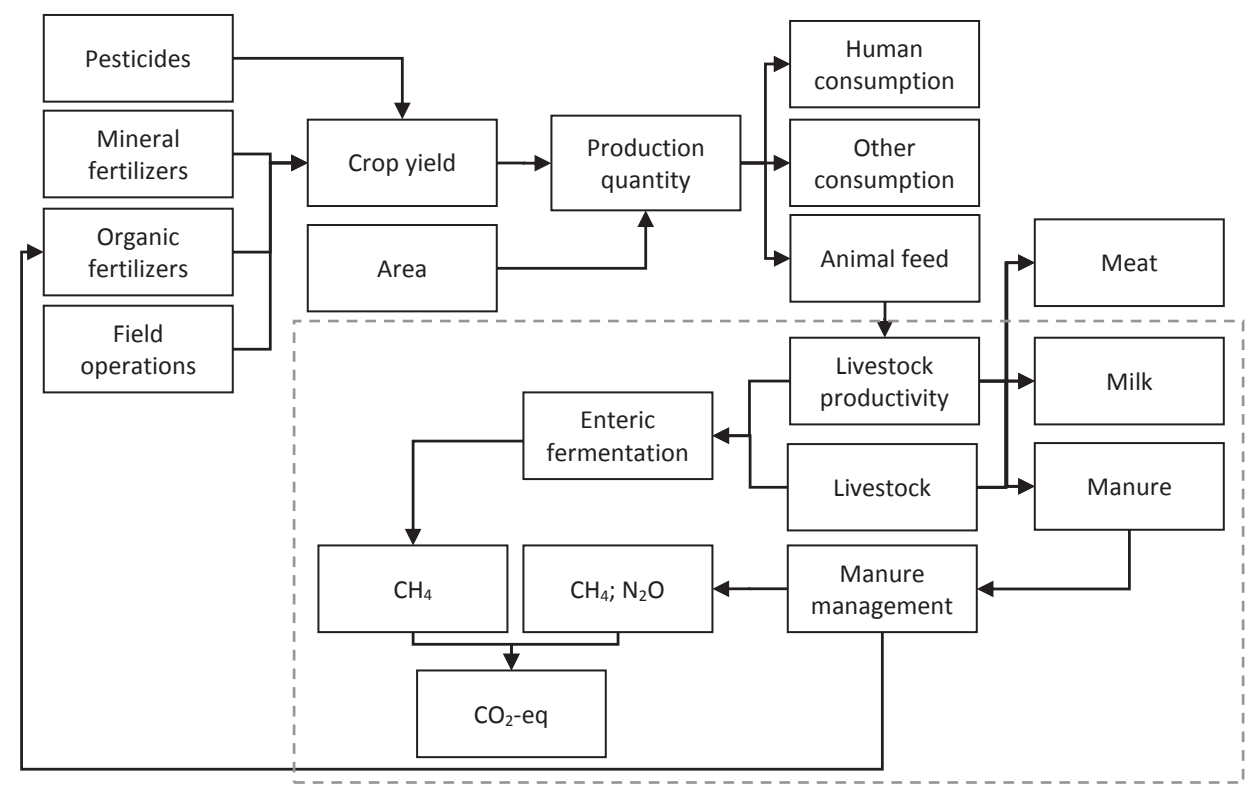

Fig. 1. Simplified block scheme of the Estonian agricultural model (crop and animal production) and sources of GHG emissions from animal production (dashed line depicts the bounds of the analysis). Source: Authors' compilation.

The database of the Estonian agricultural model includes time series data from 1992-2013 and allows for making projections up to 2020. The data is mainly from Statistics Estonia. Use of relatively short time series is related to the restoring the independence of the Republic of Estonia in 1991 that implied a structural break in the society and economy (Viira et al. 2009). The economic data from the period of planned economy and market economy are incompatible. This is a common problem for most of the post-communist Central and Eastern European countries.

According to the UNFCCC, Kyoto Protocol and EU GHG monitoring mechanism, Estonia submits annual National Inventory Report (NIR) and Common Reporting Format (CRF) tables that include GHG emission data from 1990 up until the year before last (MoE 2013). As a source of historic GHG EFs for the period of 1990-2012, this study uses data from both the 2006 IPCC Guidelines for National Greenhouse Gas Inventories (IPCC 2014) as well as Estonian NIR and CRF data submitted in 2014. 
For evaluating agricultural GHG emissions, the Estonian NIR (and CRF) mainly use data from Statistics Estonia: number of livestock by livestock category and sub-category, data on milk yield per cow, crop yields and sown areas of field crops by crop type, volume of $\mathrm{N}$ fertilizers applied on agricultural soils, location of animal waste management systems. Other data sources include Estonian Animal Recording Centre (fat content of milk, percentage of cows that give birth), scientific publications (model of energy gross intake by pigs, feed digestibility of cattle and swine, nitrogen content of feed, etc.), and National Forest Inventory NFI (activity data on organic soils) (Estonian NIR 2014).

The Estonian agricultural model includes 112 stochastic equations and 142 entities. Stochastic equations are estimated econometrically using annual data and are then solved simultaneously using two stage least squares (2SLS) and full information maximum likelihood (FIML). The Fair-Parke program is used for the estimation of model parameters (Põldaru et al. 2015). The results section of this paper presents the FIML estimations.

Two scenarios are compared in this study:

Scenario 1 (s1, baseline) is based on the situation in the milk market as of the $1^{\text {st }}$ quarter of 2015 . Considering the effects of the Russian import ban on raw milk prices in Estonia and in light of the abolishment of milk quotas in the EU, milk prices are expected to remain relatively low.

Scenario 2 (s2) considers that the Estonian Dairy Strategy 2012-2020 aims to increase Estonian milk production by $1 / 3$. This scenario imposes accelerated growth in milk yield and an increase in the number of dairy cows, which is not explicitly modelled as a reaction to price growth or policies.

In the following, a general overview is given about the equations directly involved in estimating GHG emissions from dairy cows. The definitions and descriptive statistics of variables in these equations are given in Table 1.

Table 1. Definitions and descriptive statistics of key variables

\begin{tabular}{|c|c|c|c|c|c|c|}
\hline Variable & Definition & Average & SD & Min & Max & Period \\
\hline yield & milk yield per cow, kg head ${ }^{-1} \mathrm{yr}^{-1}$ & 5362 & 1479 & 3322 & 7990 & \\
\hline milk fat & fat content of milk, \% & 4.19 & 0.10 & 4.00 & 4.34 & $1992-2013$ \\
\hline milk protein & protein content of milk, \% & 3.27 & 0.10 & 3.11 & 3.39 & \\
\hline EF1m & $\begin{array}{l}\mathrm{CH}_{4} \text { EF for enteric fermentation of } \\
\text { cow, kg CH}_{4} \text { head }^{-1} \text { year }^{-1}\end{array}$ & 109.5 & 13.9 & 89.5 & 131.2 & \\
\hline MM1m & $\begin{array}{l}\mathrm{CH}_{4} \text { EF from cow manure } \\
\text { management, } \mathrm{kg} \mathrm{CH}_{4} \text { head }^{-1} \text { year }^{-1}\end{array}$ & 5.09 & 3.24 & 2.07 & 10.52 & $1992-2012$ \\
\hline MM1d & $\begin{array}{l}\mathrm{N} \text { excretion rate per cow, } \mathrm{kg} \mathrm{N} \text { head }^{-1} \\
\text { year }^{-1}\end{array}$ & 98.1 & 11.6 & 84.1 & 118.1 & \\
\hline
\end{tabular}

Source: Estonian agricultural model's database

Milk production is a product of the number of dairy cows and the average milk yield per cow. The $\mathrm{EF}$ of $\mathrm{CH}_{4}$ of dairy cows from enteric fermentation depends on the energy that is required for subsistence, physical activity, lactation, pregnancy, growth of body weight and on the share of digestible energy (IPCC 2014). The weight and milk yield of dairy cows affect the feed intake and enteric $\mathrm{CH}_{4}$ emissions (O'Mara 2011, Weiss and Leip 2012). In this study, it is assumed that the average weight of Estonian dairy cows has not changed from 1992-2012. According to Estonian NIR (2014) and CRF (2014), the average weight of dairy cows has increased by 2-3 kg due to changes in the structure of different breeds of dairy cows. However, considering the $97.1 \%$ growth in average milk yield from 1990-2014, one could suggest that the average weight of dairy cows has increased by 150-200 kg during that period. This could be taken into account in future analyses.

If one assumes that the energy requirements of dairy cows for subsistence, activity, growth and pregnancy do not change significantly over time (i.e. the physiologic processes are normal), then the main factor that affects the EF of $\mathrm{CH}_{4}$ is energy requirements for lactation. Considering the average annual milk yield of 4,164 in 1990, 8,206 in 2014 (SE 2015) and 9,140 or 10,099 kg cow ${ }^{-1}$ projected for 2020 according to s1 and s2, one could conclude that energy requirements for lactation increase along with the rise in average yields (Estonian NIR 2014). Net energy for lactation also depends on milk fat content (IPCC 2014). While average milk yields have increased in Estonia, average milk fat content has decreased (Fig. 2). 
The EF for $\mathrm{CH}_{4}$ for dairy cows from enteric fermentation is endogenous in the model:

$$
E F 1 m=f(\text { yield, milk fat })
$$

In the model, milk fat content is a function of milk yield: an increase in average yields results in decreasing milk fat content (MoA 2012, Estonian NIR 2014). It should be noted that EFs entail certain degree of uncertainty, which depends on the availability of information that is used for the estimations. The respective uncertainty rates are provided in Estonian NIR (2014).

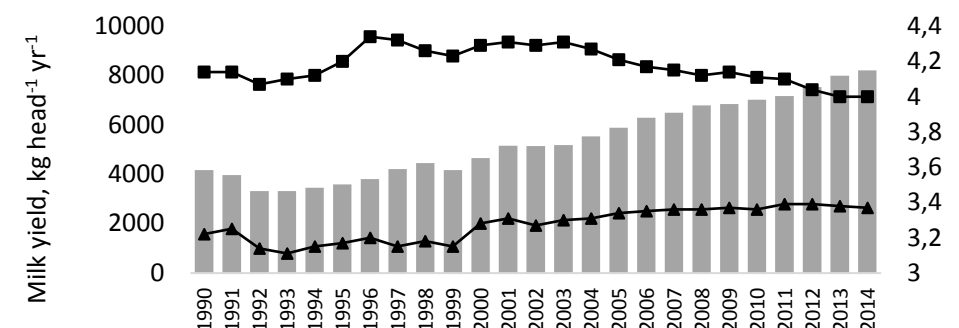

milk yield per cow, kg head-1 yr-1 $\rightarrow$ fat content of milk, \%

$\multimap$ protein content of milk, \%

Fig. 2. Average milk yield, and milk fat and protein content from 1990-2014 (ELPR 2015, SE 2015)

The emission of $\mathrm{CH}_{4}$ from manure management depends on the manure management system and the temperature of the environment. $\mathrm{CH}_{4}$ emission is affected by the manure quantity and the fraction of manure that is dissolved anaerobically. Manure handling in liquid systems increases $\mathrm{CH}_{4}$ emissions compared to solid storage systems and pasture, range and paddock (Amon et al. 2006). For Estonia, the effects of temperature (climate zones within country) are not relevant because Estonia belongs to the Atlantic continental region of the temperate zone and the average annual temperature is below $10{ }^{\circ} \mathrm{C}$ (cool climate according to the IPCC) (MoE 2013, IPCC 2014). According to the IPCC methodology, the EF for $\mathrm{CH}_{4}$ from manure management depends on volatile solid excretion per day on a dry-organic matter basis, which depends on gross energy consumption and the digestibility of the feed. Therefore, as in case of enteric fermentation, the $\mathrm{EF}$ of $\mathrm{CH}_{4}$ from manure management depends on energy intake.

Estonian CRF (2014) provides information about the proportional shares of manure managed in different systems. Up until 2001, two systems were used: solid storage systems and grazing. From 2002 onwards, the share of liquid systems began to increase. According to Estonian CRF (2014), the share of manure in liquid systems was $25.1 \%$ in 2012. However, according to estimations (MoA 2012), about $60 \%$ of Estonian dairy cows were kept in modern sheds with liquid manure systems in 2011-2014. In order to approximate the change in manure management systems from 2002-2014, it was considered that transition to liquid manure management systems is mainly related to investments that were done with the help of investment grants. Therefore, the investment grants related to cowsheds and manure management were cumulated from 2002-2014. It was assumed that the cumulated sum of investment grants in 2014 corresponds with the estimated $60 \%$ of liquid manure systems in 2014 . The increase in proportion of liquid manure systems between 2002 and 2014 was approximated based on this data and assumptions (Fig. 3).

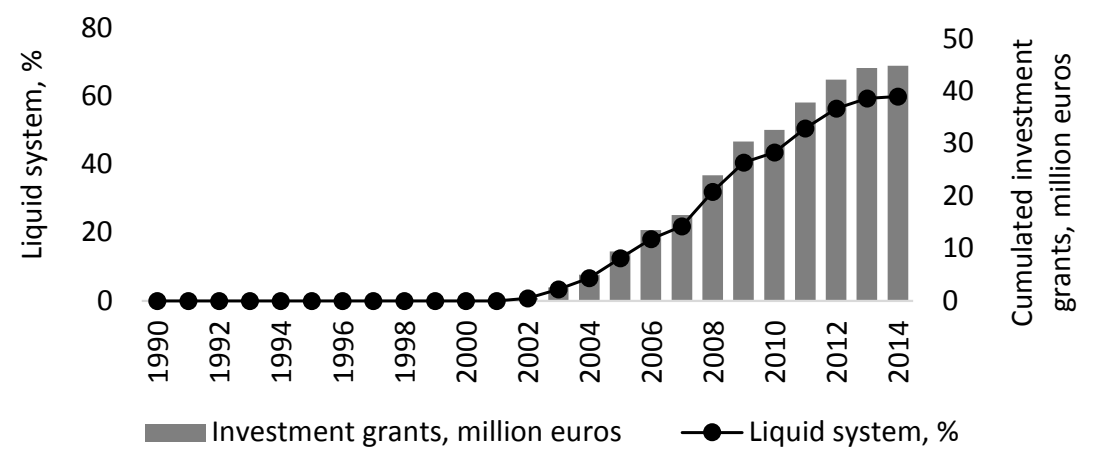

Fig. 3. Share of liquid systems in manure management and cumulated investment grants from 1990-2012 (MoA 2012, ARIB 2015, ELPR 2015, SE 2015) 
In the model, it was assumed that cows are grazed for $40 \%$ of the days in a year (146 days), 12 hours per day. Further, it was presumed that only $30 \%$ of the cows kept in cowsheds with liquid manure system, are grazed, and $70 \%$ of the cows in such systems are kept indoors throughout the year. The allocation of manure in different systems, including grazing, was estimated based on these considerations. From figure 4 it can be seen that the proportions of different manure systems in the model differ from the assumptions in the Estonian NIR.
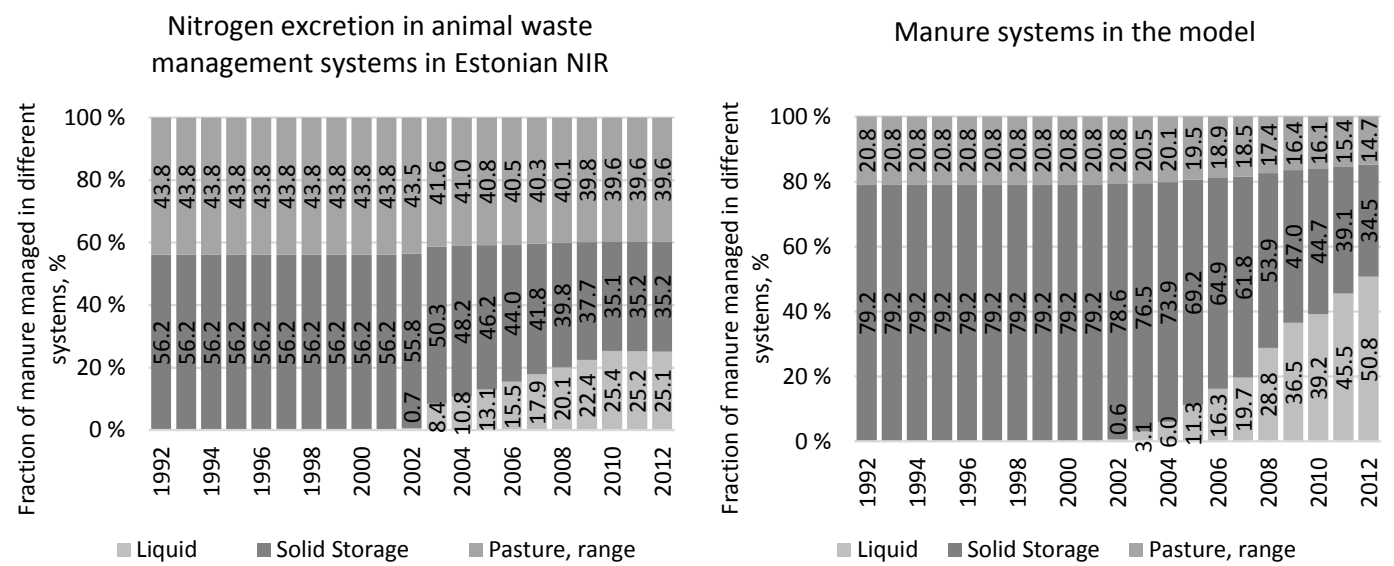

Fig. 4. Manure systems and changes in the structure of manure systems from 1992-2012 in Estonian NIR and in the model (Estonian NIR 2014, MoA 2012, ARIB 2015, ELPR 2015, SE 2015)

In the projections of s1, the number of dairy cows remains relatively unchanged and, therefore, the structure of manure management systems is stable. In s2, it is assumed that if the number of dairy cows increases, the additional cows are housed in new sheds with liquid manure management systems. Therefore, in s 2 the share of liquid systems will increase during the projected period to 58.0\%. The data from Estonian NIR (2014) are used as a background to estimate the effects of the various manure managements system assumptions on the estimations of GHG emissions.

It was assumed that if the physiologic processes are normal, the growth in milk yield results in increased energy consumption. Also, the $\mathrm{CH}_{4}$ emissions from manure management depend on changes in the structure of respective systems. In both scenarios, the same equation was used for estimating the $\mathrm{EF}$ of $\mathrm{CH}_{4}$ from manure management:

$$
M M 1 m=f(\text { yield, manure })
$$

where manure (\%) is the fraction of manure managed in liquid systems (Fig. 4, manure systems in the model).

According to the IPCC methodology, $\mathrm{N}_{2} \mathrm{O}$ emissions from manure management depend on manure nitrogen and carbon content. The amount of $\mathrm{N}_{2} \mathrm{O}$ emitted during the combined nitrification-denitrification process of nitrogen contained in the manure depends on the oxygen. This means that solid manure storage systems and manure left on grasslands foster $\mathrm{N}_{2} \mathrm{O}$ excretion. $\mathrm{N}_{2} \mathrm{O}$ emissions also depend on the average annual nitrogen excretion of dairy cows, which in turn depend on the nitrogen intake and nitrogen retention and content in milk (Estonian NIR 2014, IPCC 2014). In the case of dairy cows, nitrogen excretion (i.e. $\mathrm{N}$ content in the manure) depends on average milk yield and the average protein content of milk (Fig. 2), assuming that nitrogen intake and retention are relatively constant in the case of normal physiologic processes. The nitrogen excretion factor for dairy cows is estimated according to the following equation:

$$
\text { MM1d }=f(\text { yield, } \text { milk protein })
$$

In the model, milk protein content is a function of average milk yield per cow. In Estonia, increasing average yield has resulted in increased milk protein content (Fig. 2).

According to the IPCC methodology, the annual $\mathrm{CH}_{4}$ emission $\left(\mathrm{Gg} \mathrm{CH}_{4}\right.$ year $\left.{ }^{-1}\right)$ from enteric fermentation of dairy cows is a product of the number of dairy cows and the respective EF. The annual nitrogen excretion factor of dairy cows, structure of manure management systems, nitrogen $\mathrm{N}_{2} \mathrm{O}-\mathrm{N}$ process factors in manure management systems and $\mathrm{N}_{2} \mathrm{O}$ EF of $\mathrm{N}_{2} \mathrm{O}-\mathrm{N}$ emissions are taken into account when estimating the annual $\mathrm{N}_{2} \mathrm{O}$ emission (IPCC 2014). 
In estimating the $\mathrm{CO}_{2}$-eq of the projected GHG emissions (global warming emissions) Global Warming Potential (GWP) for $\mathrm{CH}_{4}$, both 21 and 25 was used; for $\mathrm{N}_{2} \mathrm{O}$, both 310 and 298 were used (IPCC 2007, Crosson et al. 2011, EPA 2013, IPCC 2014, UNFCCC 2014a). Therefore, it was possible to estimate the contribution of GHG emissions to the greenhouse effect in two ways.

In order to estimate the "carbon footprint" of milk production, the projected raw milk was converted to energy corrected milk (ECM) according to the milk standard of $4 \%$ fat and 3.3\% protein (IFCN, 2015):

$$
E C M=(\text { milk production } \times(0.383 \times \% \text { fat }+0.242 \times \% \text { protein } \times 0.7832) / 3.1138)(4)
$$

Both, $\mathrm{CH}_{4}$ from enteric fermentation and manure management, as well as $\mathrm{N}_{2} \mathrm{O}$ and $\mathrm{CO}_{2}$-eq were estimated for one $\mathrm{kg}$ of $\mathrm{ECM}\left(\mathrm{kg} \mathrm{GHG} \mathrm{kg} \mathrm{ECM}{ }^{-1}\right)$.

\section{Results and discussion}

According to the projections, milk production will intensify in Estonia. By 2020, compared to 2014, the average milk yield will increase by $11.4 \%$ in the case of $s 1$ and by $23.1 \%$ in $s 2$ (Table 2 ). The projected number of cows in s2 is 109.2 thousand. Therefore, in s2, milk production would amount to 1.1 million tons by 2020 . According to the projections of s1, there will be 95.5 thousand dairy cows in 2020 with average yield of 9,140 kg cow ${ }^{-1}$ and total milk production of 872 thousand tonnes.

Table 2. The actual $(1990,2005,2012,2014)$ and projected (2015-2020) number of dairy cows, average milk yield, milk production and GHG emissions

\begin{tabular}{|c|c|c|c|c|c|c|c|c|}
\hline & & 1990 & 2005 & 2012 & 2014 & 2015 & 2020 & $\begin{array}{l}\text { Change from } \\
\text { 2014-2020, \% }\end{array}$ \\
\hline \multirow{2}{*}{ Cows, thousand heads } & s1 & 280.7 & 112.8 & 96.8 & 95.1 & 95.3 & 95.4 & $0.3 \%$ \\
\hline & s2 & 280.7 & 112.8 & 96.8 & 95.1 & 101.3 & 109.2 & $14.8 \%$ \\
\hline \multirow{2}{*}{ Yield, kg head ${ }^{-1}$ year $^{-1}$} & s1 & 4,164 & 5,886 & 7,526 & 8,206 & 8,259 & 9,140 & $11.4 \%$ \\
\hline & s2 & 4,164 & 5,886 & 7,526 & 8,206 & 8,531 & 10,098 & $23.1 \%$ \\
\hline \multirow{2}{*}{ Milk production, thousand tonnes } & s1 & $1,208.0$ & 670.4 & 721.2 & 799.3 & 786.9 & 872.0 & $9.1 \%$ \\
\hline & s2 & $1,208.0$ & 670.4 & 721.2 & 799.3 & 864.2 & $1,102.5$ & $37.9 \%$ \\
\hline \multirow{2}{*}{$\begin{array}{l}\text { GHG emissions GWP 21/310, Gg CO } \text { CO }^{-} \\
\text {eq year }{ }^{-1}\end{array}$} & s1 & 839.4 & 386.8 & 371.7 & 354.0 & 354.9 & 375.3 & $6.0 \%$ \\
\hline & s2 & 839.4 & 386.8 & 371.7 & 360.6 & 382.4 & 448.5 & $24.4 \%$ \\
\hline \multirow{2}{*}{$\begin{array}{l}\text { GHG emissions GWP 25/298, Gg CO }{ }_{2}^{-} \\
\text {eq year }^{-1}\end{array}$} & s1 & 839.4 & 386.8 & 371.7 & 408.7 & 409.8 & 433.2 & $6.0 \%$ \\
\hline & s2 & 839.4 & 386.8 & 371.7 & 416.4 & 441.9 & 518.5 & $24.5 \%$ \\
\hline \multirow{2}{*}{$\begin{array}{l}\text { GHG emissions per } \mathrm{kg} \text { of milk GWP } \\
21 / 310, \mathrm{~kg} \mathrm{CO}_{2} \text {-eq } \mathrm{kg} \mathrm{ECM}^{-1}\end{array}$} & s1 & 0.687 & 0.561 & 0.510 & 0.453 & 0.452 & 0.443 & $-2.1 \%$ \\
\hline & s2 & 0.687 & 0.561 & 0.510 & 0.453 & 0.447 & 0.436 & $-3.9 \%$ \\
\hline \multirow{2}{*}{$\begin{array}{l}\text { GHG emissions per } \mathrm{kg} \text { of milk GWP } \\
25 / 298, \mathrm{~kg} \mathrm{CO}_{2} \text {-eq kg ECM }{ }^{-1}\end{array}$} & s1 & 0.687 & 0.561 & 0.510 & 0.523 & 0.522 & 0.512 & $-2.1 \%$ \\
\hline & s2 & 0.687 & 0.561 & 0.510 & 0.523 & 0.516 & 0.504 & $-3.7 \%$ \\
\hline
\end{tabular}

Source: projections of the Estonian agricultural model, Estonian NIR 2014, Estonian CRF 2014, SE 2015

The projected $\mathrm{EF}$ of $\mathrm{CH}_{4}$ from enteric fermentation (EF1m) will increase by $10.2 \%$ in s1 and by $15.7 \%$ in s2 (Fig. 5). The emissions of $\mathrm{CH}_{4}$ from enteric fermentation (MEf1) will increase in s1 by $8.6 \%$ and in s2 by $30.4 \%$. While the growth in $\mathrm{CH}_{4}$ emissions is affected by the growth of respective $\mathrm{EF}$ and growth in the number of dairy cows, the relative growth in $\mathrm{CH}_{4}$ emissions remains below the growth figures for milk production. Therefore, the $\mathrm{CH}_{4}$ emissions from enteric fermentation per $\mathrm{kg}$ of milk (ECM) will decrease by $6.4 \%$ in s1 and by $7.5 \%$ in s 2 by 2020 , compared to 2012. This implies that productivity growth results in reduced GHG emissions per kg of milk (ECM), i.e. the relative negative effects of the production of $\mathrm{kg}$ of milk (ECM) on climate change will decline. 


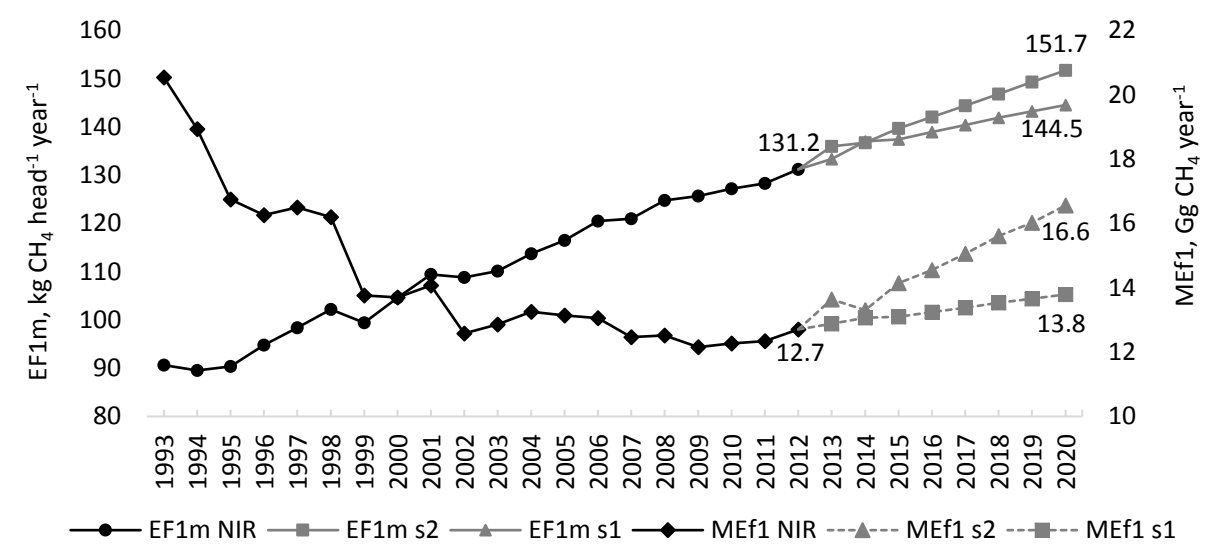

Fig. 5. Actual and projected $\mathrm{EF}$ of $\mathrm{CH}_{4}\left(\mathrm{EF} 1 \mathrm{~m}, \mathrm{~kg} \mathrm{CH}_{4}\right.$ head ${ }^{-1}$ year $\left.{ }^{-1}\right)$ and $\mathrm{CH}_{4}$ emissions (MEf1, $\mathrm{Gg} \mathrm{CH}_{4}$ year ${ }^{-1}$ ) from enteric fermentation in 1993-2020 (projections of the Estonian agricultural model, Estonian NIR 2014, Estonian CRF 2014)

The $\mathrm{EF}$ of $\mathrm{CH}_{4}$ from manure management (MM1m) will increase by $25.4 \%$ according to $\mathrm{s} 1$ and by $39.4 \%$ in $\mathrm{s} 2$ by 2020, compared to 2012 (Fig. 6). By 2020, compared to 2012, the emissions of $\mathrm{CH}_{4}$ from manure management (MEs1) will increase by $23.4 \%$ in $\mathrm{s} 1$ and by $57.0 \%$ in s2. This growth is due to an increase in average yields, increase in the number of cows and increase in the proportion of liquid manure management systems in $\mathrm{s} 2$. Assuming that in the period 2014-2020 the share of liquid systems in manure management will increase to 58\% and the share of solid manure systems will decrease to $28 \%$, according to $\mathrm{s} 2$, the $\mathrm{CH}_{4}$ emissions from manure management per $\mathrm{kg}$ of milk (ECM) will increase by $11.1 \%$ in $\mathrm{s} 2$. In s1, the growth will be $6.2 \%$.

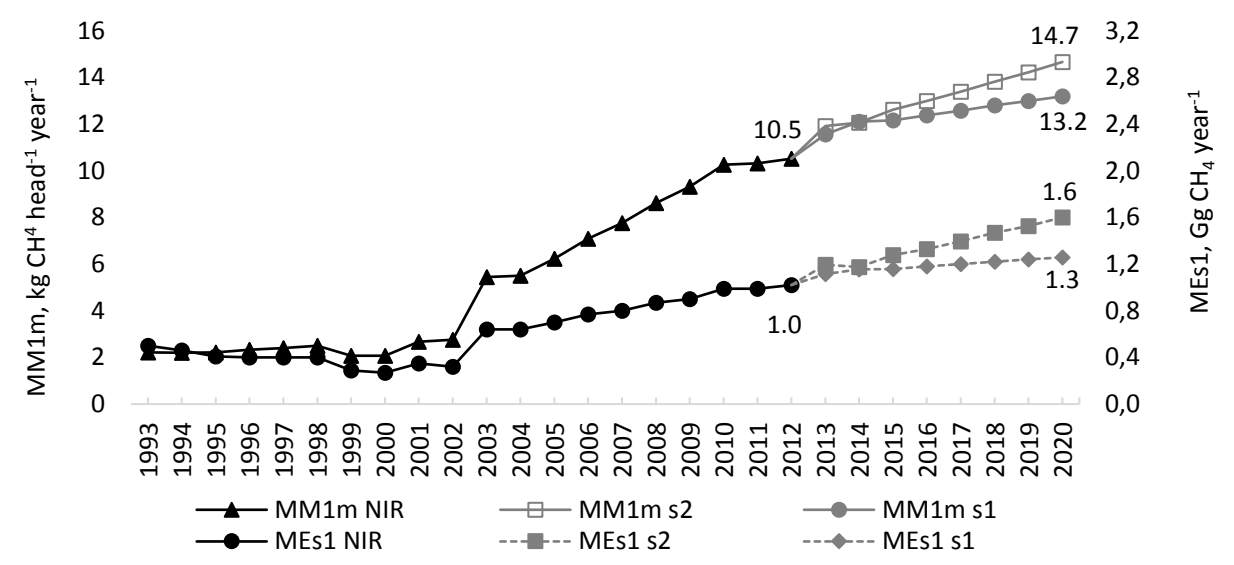

Fig. 6. Actual and projected $\mathrm{EF}$ of $\mathrm{CH}_{4}\left(\mathrm{MM} 1 \mathrm{~m}, \mathrm{~kg} \mathrm{CH}_{4}\right.$ head ${ }^{-1}$ year ${ }^{-1}$ ) and $\mathrm{CH}_{4}$ emissions (MEs1, $\mathrm{Gg} \mathrm{CH}_{4}$ year $^{-1}$ ) from manure management in 1993-2020 (projections of the Estonian agricultural model, Estonian NIR 2014, Estonian CRF 2014)

The annual average nitrogen excretion factor (MM1d) per dairy cow will increase by $11.0 \%$ in $\mathrm{s} 1$ and $18.8 \%$ in s2 by 2020, compared to 2012 (Fig. 7). Compared to 2012 figures from NIR, annual $\mathrm{N}_{2} \mathrm{O}$ emissions from manure management (DEs1) will decrease by $29.1 \%$ in s1 and by $19.9 \%$ in $s 2$. This decline is mainly due to the differences in manure management systems in NIR and in this study. Up until 2007, the NIR and our estimations regarding manure management systems do not differ significantly. However, since 2008, the difference is increasing and, in 2012 , the difference is already twice. If one considers the data used in the model, there is a $6.7 \%$ increase in $\mathrm{N}_{2} \mathrm{O}$ emissions according to $\mathrm{s} 1$ and a $13.6 \%$ increase according to $\mathrm{s} 2 . \mathrm{N}_{2} \mathrm{O}$ emissions from manure management per $\mathrm{kg}$ of milk (ECM) will decrease $43.5 \%$ in $\mathrm{s} 1$ and by $47.5 \%$ in $\mathrm{s} 2$ by 2020 . If the estimates projected by the model for both 2012 and 2020 are considered, then $\mathrm{N}_{2} \mathrm{O}$ emissions from manure management per kg of milk (ECM) will decrease by $9.2 \%$ in $\mathrm{s} 1$ and by $14.8 \%$ in s2. Compared to our projections, the NIR data on $\mathrm{N}_{2} \mathrm{O}$ emissions from manure management is underestimated. This implies that the data on manure management systems need to be further specified. 


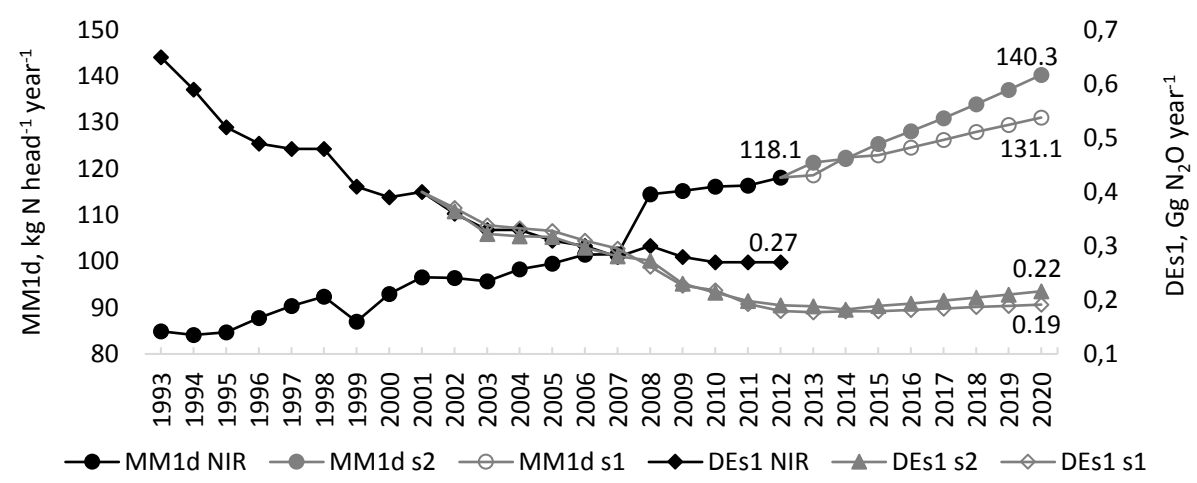

Fig. 7. Actual and projected nitrogen excretion factor (MM1d, $\mathrm{kg} \mathrm{N}$ head $^{-1}$ year $^{-1}$ ) and $\mathrm{N}_{2} \mathrm{O}$ emissions (DEs1, Gg N${ }_{2} \mathrm{O}_{\text {year }}{ }^{-1}$ ) from manure management in 1993-2020 (projections of the Estonian agricultural model, Estonian NIR 2014, Estonian CRF 2014)

According to the projections, the GHG emission from dairy cows in $\mathrm{CO}_{2}$-eq $\left(\mathrm{CH}_{4} \mathrm{GWP} 21\right.$ and $\mathrm{N}_{2} \mathrm{O}$ GWP 310) will increase by 2020 , compared to 2012 , by $1.0 \%$ according to $s 1$ and by $20.7 \%$ in s2 (Table 2). The majority (more than 70\%) of the GHG emissions in $\mathrm{CO}_{2}$-eq, both in 2012 and 2020, are originating from enteric fermentation. GHG emissions from manure management contribute to $22 \%$ of total GHG emissions from dairy cows. According to projections, in $2020, \mathrm{CH}_{4}$ emissions from manure management will contribute $7 \%$ and $\mathrm{N}_{2} \mathrm{O}$ emissions from manure management $15 \%$ of total GHG emissions from dairy cows. In 2012, these figures were $6 \%$ and $23 \%$ respectively, implying that the adoption of liquid manure management systems increases the $\mathrm{CH}_{4}$ share and reduces $\mathrm{N}_{2} \mathrm{O}$ share as a source of GHG emissions.

If, alternatively, $\mathrm{CH}_{4}$ GWP 25 and $\mathrm{N}_{2} \mathrm{O}$ GWP 298 were used to estimate the global warming potential of GHG emitted by dairy cows, then global warming emissions would increase by $16.5 \%$ according to s1 and by $39.5 \%$ according to 22 compared to the GHG emissions in $\mathrm{CO}_{2}$-eq as reported in Estonian NIR and CRF.

Conversion of $\mathrm{CH}_{4}$ and $\mathrm{N}_{2} \mathrm{O}$ to $\mathrm{CO}_{2}$-eq reveals that different GWP factors change the estimated effects of GHG emissions on the environment. The increased use of liquid manure systems increases $\mathrm{CH}_{4}$ emissions and reduces $\mathrm{N}_{2} \mathrm{O}$ emissions. The negative effect of increased $\mathrm{CH}_{4}$ emissions in the case of GWP 21 is lower than the positive effect of reduced $\mathrm{N}_{2} \mathrm{O}$ in the case of GWP 310. As a result, the GHG emissions in $\mathrm{CO}_{2}$-eq will increase less than in the case of $\mathrm{CH}_{4}$ GWP 25 and $\mathrm{N}_{2} \mathrm{O}$ GWP 298 (Table 2). If the GWP of $\mathrm{CH}_{4}$ increases to 25, the negative effect of increased $\mathrm{CH}_{4}$ emissions will then exceed the positive effect of reduced $\mathrm{N}_{2} \mathrm{O}$ (GWP 298) emissions.

The GHG emissions per kg of milk (ECM) in $\mathrm{CO}_{2}$-eq $\left(\mathrm{CH}_{4}\right.$ GWP 21 and $\mathrm{N}_{2} \mathrm{O}$ GWP 310) will decrease by $13.0 \%$ in scenario 1 and by 14.5\% in scenario 2 by 2020, compared to 2012. In the case of $\mathrm{CH}_{4}$ GWP 25 and $\mathrm{N}_{2} \mathrm{O}$ GWP 298, the GHG emissions per kg of milk (ECM) in $\mathrm{CO}_{2}$-eq will decrease by $13.2 \%$ in s1 and by $11.8 \%$ in s2.

Estonia is required to ensure that GHG emissions in agriculture in 2020 do not exceed $111 \%$ of the 2005 levels (MoA 2013). According to s1, GHG emissions in $\mathrm{CO}_{2}$-eq will decrease from 2005 to 2020 by $3.0 \%$ in case of GWP 21/310, and will increase by $12.0 \%$ in case of GWP $25 / 298$. In s2, the equivalent change in $\mathrm{CO}_{2}$-eq would be $16.0 \%$ in case of GWP $21 / 310$ and $34.0 \%$ in case of $25 / 298$. This implies that realising the production growth target of Estonian dairy strategy would jeopardise Estonian commitments related to agricultural GHG emissions, indicating a discrepancy between the two strategies. In order to address this mismatch, the dairy strategy should associate the growth targets with appropriate measures that help to reduce the GHG emissions: e.g. introduction of improved feeding technologies as suggested by Grainger and Beauchemin (2011), Gerber et al. (2013), Opio et al. (2013); and introduction of manure management technologies that reduce GHG emissions as suggested by Gerber et al. (2013).

There results suggest that both the data on the manure management systems and various GWP coefficients have an effect on estimated GHG emissions. This further illustrates that the projections of GHG emissions and evaluation of the effects of policies on the reduction of GHG emissions has scope of some uncertainty. 


\section{Conclusions}

The scope of this study was limited to the analysis of GHG emissions arising from the enteric fermentation of dairy cows and associated manure management. However, having regard for the limitations of the study, the projected results illustrate that achieving the economic targets of Estonian dairy strategy (increase milk production by $1 / 3$ by 2020) would cause increase in GHG emissions that exceeds the growth agreed upon in current agreements.

The projected increase in milk production by $37.9 \%$ by 2020 will result in a $24.5 \%$ increase in GHG emissions $\left(\mathrm{CO}_{2}-\right.$ eq). This implies that increasing the milk yield per cow will result in reduced GHG emissions ("carbon footprint") per $\mathrm{kg}$ of milk. The results of the study reveal that the estimates of GHG emissions also depend on the assumptions and information about the manure management systems (technologies) used in the farms.

The study showed that modelling the GHG emissions in the framework of partial equilibrium model of Estonian agriculture, enables to get more justified results compared to approach, where projected of number of animals is multiplied with static emission factors in order to get the total GHG emissions from agricultural sub-sectors. In the light of these results, the stakeholders of the process of Estonian dairy strategy could review the set of environmental measures in order to better balance the economic and environmental aspects of sustainable agriculture.

However, in the future, the comparison of projected GHG emissions and agreed emission targets should be analysed in a more holistic system that accounts also for other sub-sectors of animal and crop production. Considering that besides milk production, Estonian agricultural model includes the projections of other animal production, production of cereals and oilseeds, the model could be complemented with modules for estimations of respective GHG emissions.

\section{Acknowledgements}

This study was part of the research project "The Analysis of Changes in Agricultural Commodity Prices and Structure of Estonian Main Agricultural Products. The Approach Based on Macroeconomic Models", financed under the national "Agricultural and Applied Research and Development Program 2009-2014". The authors thank the two anonymous reviewers for their useful comments.

\section{References}

AHDB 2014. Greenhouse gas emissions on British dairy farms. DairyCo carbon foot printing study: Year Three (2012-2013). Agriculture and Horticulture Development Board, Kenilworth. Carbon footprint report 2014. 17 p. http://dairy.ahdb.org.uk/media/988076/411045_carbon_footprint_report_year_3_final.pdf. Accessed 18 June 2015.

Amon, B., Kryvoruchko, V., Amon, T. \& Zechmeister-Boltenstern, S. 2006. Methane, nitrous oxide and ammonia emissions during storage and after application of dairy cattle slurry and influence of slurry treatment. Agriculture, Ecosystems and Environment 112: 153-162.

ARIB 2015. Database on beneficiaries of investment grants. Data received from Department of Rural Economy Research of the Institute of Economics and Social Sciences of Estonian University of Life Sciences.

Bannink, A., van Schijndel, M.W. \& Dijkstra, J. 2011. A model of enteric fermentation in dairy cows to estimate methane emission for the Dutch National Inventory Report using the IPCC Tier 3 approach. Animal Feed Science and Technology 166-167: 603-618.

Casey, J.W. \& Holden, N.M. 2005. Analysis of greenhouse gas emissions from the average Irish milk production system. Agricultural Systems 86: 97-114.

Crosson, P., Shalloo, L., O’Brien, D., Lanigan, G.J., Foley, P.A., Boland, T.M. \& Kenny, D.A. 2011. A review of whole farm systems models of greenhouse gas emissions from beef and dairy cattle production systems. Animal Feed Science and Technology 166-167: 29-45.

Donnellan, T., Hanrahan, K., Breen, J.P. \& Gillespie, P. 2013. Climate Change and Agricultural Policy Coherence: Agricultural Growth and GHG Emissions in Ireland. Paper presented at the 87th Agricultural Economics Society Annual Conference, in April in Warwick University, Coventry, UK. http://purl.umn.edu/158853. Accessed 8 April 2015.

ELPR 2015. Results of animal recording in Estonia 2014. Estonian Livestock Performance Recording Ltd (ELPR), Estonia. 52 p. https://www.jkkeskus.ee/assets/tekstid/aastaraamatud/aastaraamat_2014.pdf. Accessed 18 June 2015.

EC 2014. 2030 Climate and energy policy framework. European Council conclusions. 23/24 October 2014, European Council, Brussels. 15 p. http://www.consilium.europa.eu/uedocs/cms_data/docs/pressdata/en/ec/145397.pdf. Accessed 5 November 2014.

EC 2015. EU action on climate. http://ec.europa.eu/clima/policies/brief/eu/index_en.htm. Accessed 30 March 2015.

EPA 2013. 2013 Revisions to the Greenhouse Gas Reporting Rule and Final Confidentiality Determinations for New or Substantially Revised Data Elements. Environmental Protection Agency (EPA), United States. 292 p. http://www.epa.gov/ghgreporting/ documents/pdf/2013/documents/2013-data-elements.pdf. Accessed 22 March 2015. 
Espenberg, S., Kuhi-Thalfeldt, R., Lahtvee, V., Jüssi, M., Moora, H., Laht, J., Mander, Ü., Salm, J-O. \& Parts, K. 2013. Eesti võimalused liikumaks konkurentsivõimelise madala süsinikuga majanduse suunas aastaks 2050. Ministry of the Environment, Estonia. Lõppraport. 429 p. http://www.sei-international.org/publications?pid=2701. Accessed 15 January 2015. (in Estonian)

Estonian CRF 2014. Greenhouse gas emissions in Estonia 1990-2012. Common Reporting Format. United Nations Framework Convention on Climate Change (UNFCCC). https://unfccc.int/files/national_reports/annex_i_ghg_inventories/national_inventories_submissions/application/zip/est-2014-crf-10oct.zip. Accessed 4 November 2015.

Estonian NIR 2014. Greenhouse gas emissions in Estonia 1990-2012. National inventory report. United Nations Framework Convention on Climate Change (UNFCCC). https://unfccc.int/files/national_reports/annex_i_ghg_inventories/national_inventories_ submissions/application/zip/est-2014-nir-15apr.zip . Accessed 4 November 2015.

EU CRF 2014. Annual European Union greenhouse gas inventory 1990-2012 and inventory report 2014. Convention. United Nations Framework Convention on Climate Change (UNFCCC). http://unfccc.int/files/national_reports/annex_i_ghg_inventories/ national_inventories_submissions/application/zip/euc-2014-crf-24nov.zip. Accessed 15 May 2015.

Frelih-Larsen, A., MacLeod, M., Osterburg, B., Eory, A.V., Dooley, E., Kätsch, S., Naumann, S., Rees, B., Tarsitano, D., Topp, K., Wolff, A., Metayer, N., Molnar, A., Povellato, A., Bochu, J.L., Lasorella, M.V. \& Longhitano, D. 2014. Mainstreaming climate change into rural development policy post 2013. Ecologic Institute, Berlin. Final report. $491 \mathrm{p}$. http://www.ecologic.eu/sites/files/project/2015/ documents/mainstreaming_climatechange_rdps_post2013_final_0.pdf. Accessed 12 March 2015.

Gerber, P.J., Steinfeld, H., Henderson, B., Mottet, A., Opio, C., Dijkman, J., Falcucci, A. \& Tempio, G. 2013. Tackling climate change through livestock - A global assessment of emissions and mitigation opportunities. Food and Agriculture Organization of the United Nations (FAO), Rome. 116 p. http://www.fao.org/docrep/018/i3437e/i3437e.pdf. Accessed 24 March 2015.

Grainger, C. \& Beauchemin, K.A. 2011. Can enteric methane emissions from ruminants be lowered without lowering their production? Animal Feed Science and Technology 166-167: 308-320.

Hanrahan, K.F. 2001. The EU GOLD Model 2.1: An introductory manual. Teagasc, Dublin. Rural Economy Research Centre. http:// www.tnet.teagasc.ie/agmemod/downloads/goldmanualdft.pdf. Accessed 23 January 2002.

Hristov, A.N., Oh, J., Lee, C., Meinen, R., Montes, F., Ott, T., Firkins, J., Rotz, A., Dell, C., Adesogan, A., Yang, W., Tricarico, J., Kebreab, E., Waghorn, G., Dijkstra, J. \& Oosting, S. 2013. Mitigation of greenhouse gas emissions in livestock production - A review of technical options for non-CO2 emissions. In: Gerber, P.J., Henderson, B. \& Makkar, H.P.S. (eds.). FAO Animal Production and Health Paper No. 177. FAO, Rome, Italy. 212 p. http://www.fao.org/docrep/018/i3288e/i3288e.pdf. Accessed 11 March 2015.

IFCN 2015. Dairy Network. Dairy Sector \& Country Page Analysis. http://www.ifcndairy.org/en/methods/dairysector/index.php Accessed 17 March 2015.

Ingram, J., Ericksen, P. \& Liverman, D. 2010. Food Security and Global Environmental Change. London and Washington, DC: Earthscan. 362 p. http://www.gecafs.org/publications/Publications/Food_Security_and_Global_Environmental_Change.pdf. Accessed 15 March 2015.

IPCC 2007. Climate Change 2007 - The Physical Science Basis. Contribution of Working Group I to the Fourth Assessment Report of the Intergovernmental Panel on Climate Change. Cambridge: Cambridge University Press. 996 p. http://www.ipcc.ch/pdf/assessment-report/ar4/wg1/ar4_wg1_full_report.pdf. Accessed 22 March 2015.

IPCC 2014. 2006 IPCC Guidelines for National Greenhouse Gas Inventories. The Intergovernmental Panel on Climate Change (IPCC). http://www.ipcc-nggip.iges.or.jp/public/2006gl/index.html. Accessed 6 March 2015.

IPCC 2015. Climate Change 2014: Synthesis Report. Contribution of Working Groups I, II and III to the Fifth Assessment Report of the Intergovernmental Panel on Climate Change [Core Writing Team, Pachauri, R.K. and Meyer, L.A. (eds.)]. Geneva, Switzerland. IPCC. 151 p. https://www.ipcc.ch/pdf/assessment-report/ar5/syr/SYR_AR5_FINAL_full.pdf. Accessed 6 April 2015.

Lengers, B., Britz, W. \& Holm-Müller, K. 2013. Comparison of GHG-Emission Indicators for Dairy Farms with Respect to Induced Abatement Costs, Accuracy, and Feasibility. Applied Economic Perspectives and Policy 35: 451-475.

Meyers, W.H., Westhoff, P., Fabiosa, J.F. \& Hayes, D.J. 2010. The FAPRI global modeling system and outlook process. Journal of international agricultural trade and development 6: 1-19.

MoA 2012. Eesti piimanduse strateegia 2012-2020. Ministry of Agriculture, Estonia. 37 p. http://www.agri.ee/sites/default/files/ public/juurkataloog/ARENDUSTEGEVUS/piimandusstrateegia-2012-2020.pdf. Accessed 3 February 2015. (in Estonian)

MoA 2013. Põllumajandussektoris kliimamuutuste leevendamise ja kliimamuutustega kohanemise tegevuskava 2012-2020. Ministry of Agriculture, Estonia. 27 p. http://agri.ee/sites/default/files/public/juurkataloog/ARENDUSTEGEVUS/kliimamuutused-tegevuskava-2012-2020.pdf. Accessed 12 April 2015. (in Estonian)

MoE 2001. Estonia's third national communication. Under the UN Framework Convention on Climate Change. Ministry of the Environment, Estonia. 83 p. http://unfccc.int/resource/docs/natc/estnc3.pdf. Accessed 13 March 2015.

MoE 2013. Estonia's sixth national communication. Under the United Nations Framework Convention on Climate Change. Ministry of the Environment, Estonia. 260 p. http://unfccc.int/files/national_reports/non-annex_i_natcom/application/pdf/est_nc6. pdf. Accessed 6 March 2015.

O'Mara, F.P. 2011. The significance of livestock as a contributor to global greenhouse gas emissions today and in the near future. Animal Feed Science and Technology 166-167: 7-15.

OECD 2012a. OECD Environmental Outlook to 2050: The Consequences of Inaction. OECD Publishing, Paris. 351 p. DOI: http:// dx.doi.org/10.1787/9789264122246-en. Accessed 10 April 2015.

OECD 2012b. Sustainable agricultural productivity growth and bridging the gap for small family farms. Interagency Report to the Mexican G20 Presidency, coordinated by FAO and the OECD. 89 p. http://www.oecd.org/tad/agricultural-policies/50544691.pdf . Accessed 24 March 2015. 
Opio, C., Gerber, P., Mottet, A., Falcucci, A., Tempio, G., MacLeod, M., Vellinga, T., Henderson, B. \& Steinfeld, H. 2013. Greenhouse gas emissions from ruminant supply chains - A global life cycle assessment. Food and Agriculture Organization of the United $\mathrm{Na}$ tions (FAO), Rome. Report. 192 p. http://www.fao.org/docrep/018/i3461e/i3461e.pdf. Accessed 11 April 2015.

Põldaru, R., Roots, J., Viira, A.-H. 2013. Globaalne makromudel piimatoodete hindade prognoosimiseks (in Estonian). Piimafoorum 2013: 29-33.

Põldaru, R., Viira, A-H., Ariva, J. \& Roots, J. 2015. Modelling the meat sector in Estonia. Economic science for rural development. Proceedings of the 16th International Scientific Conference, in April in Jelgava, Latvia. LLU ESAF 37: 54-63.

Rotz, C.A., Montes, F. \& Chianese, D.S. 2010. The carbon footprint of dairy production systems through partial life cycle assessment. Journal of Dairy Science 93: 1266-1282.

SAIC 2006. Life Cycle assessment: Principles and Practice. Scientific Applications International Corporation (SAIC). p. 1-6. http:// www.epa.gov/nrmrl/std/lca/pdfs/chapter1_frontmatter_lca101.pdf. Accessed 25 March 2015.

SE 2015. Statistics Estonia. Online statistical database. http://www.stat.ee/en. Accessed 2 February 2015.

UNFCCC 2014a. Global Warming Potentials. http://unfccc.int/ghg_data/items/3825.php. Accessed 22 March 2015.

UNFCCC 2014b. Kyoto Protocol. http://unfccc.int/kyoto_protocol/items/2830.php. Accessed 18 March 2015.

UNFCCC 2014c. Pre-2020 Ambition. http://unfccc.int/focus/mitigation/pre_2020_ambition/items/8165.php. Accessed 18 March 2015.

USEPA 2012. Global Anthropogenic Non-CO2 Greenhouse Gas Emissions: 1990-2030. United States Environmental Protection Agency (USEPA), United States. Report. 176 p. http://www.epa.gov/climatechange/Downloads/EPAactivities/EPA_Global_NonCO2_Projections_Dec2012.pdf. Accessed 8 April 2015.

Van Doorslaer, B., Witzke, I.H., Weiss, F., Fellmann, T., Salputra, G., Jansson, T., Drabik, D. \& Leip, A. 2015. An economic assessment of GHG mitigation policy options for EU agriculture. Institute for Prospective Technological Studies, Publications Office of the European Union, Luxembourg. Report. 122 p. http://publications.jrc.ec.europa.eu/repository/handle/JRC93434. Accessed 20 February 2015.

Viira, A.-H., Põder, A. \& Värnik, R. 2009. 20 years of transition - institutional reforms and the adaptation of production in Estonian agriculture. Agrarwirtschaft 58: 294-303.

Von Keyselingk, M.A.G., Martin, N.P., Kebreab, E., Knowlton, K.F., Grant, R.J., Stephenson, M., Sniffen, C.J., Parner, J.P., Wright, A.D. \& Smith, S.I. 2013. Sustainability of the US dairy industry. Journal of Dairy Science 96: 5405-5425.

Weiss, F. \& Leip, A. 2012. Greenhouse gas emissions from the EU livestock sector: A life cycle assessment carried out with the CAPRI model. Agriculture, Ecosystems and Environment 149: 124-134. 